\title{
Analisis Kesalahan Penggunaan Kata Hasil Terjemahan Indonesia-Jepang dalam Karya IImiah Mahasiswa
}

\author{
Asep Achmad Muhlisian \\ STBA YAPARI - ABA Bandung \\ Email : achmadmuhlisian@gmail.com
}

\begin{abstract}
ABSTRAK
Kompleksnya proses penerjemahan dapat menimbulkan kesalahan penerjemahan. Studi kasus (Case Study) ini menganalisis kesalahan penggunaan kata bahasa Jepang dalam hasil terjemahan IndonesiaJepang. Sumber datanya adalah sembilan karya ilmiah mahasiswa. Hasil analisis menunjukkan lima kategorisasi kesalahan: 1) Kesalahan penggunaan kosakata yang tidak sesuai dalam kalimat. 2) Kesalahan penambahan dan penghilangan kata dalam kalimat, 3) Kesalahan penulisan huruf katakana, 4) Kesalahan penulisan kanji, dan 5) kesalahan perubahan kata. Kesalahan tersebut disebabkan oleh lima faktor, yaitu, 1) Language Transfer, 2) Overgeneralization 3) Transfer of Training, 4) Learning Strategy 5) Communication Strategy.

Kata kunci: Analisis kesalahan, penerjemahan Indonesia-Jepang, penggunaan kata
\end{abstract}

\section{ABSTRACT}

The complexity of the translation process can lead to errors in translation. This case study analyzes the misuse of the Japanese word in Indonesian-Japanese translation. The data source is the nine scientific works of students majoring in Japanese. The results of the analysis show five categorizations of error: 1) Mistakes of inappropriate vocabulary in the sentence. 2) Error adding and omission of words in sentence, 3) Error writing letters saya, 4) Kanji writing error, and 5) error word change. The error is caused by five factors, namely, 1) Language Transfer, 2) Overgeneralization 3) Transfer of Training, 4) Learning Strategy 5) Communication Strategy

Key words: Error analysis, Japanese words, IndonesianJapanese translation 


\section{Pendahuluan}

Penerjemahan merupakan suatu proses yang kompleks sehingga dapat menimbulkan masalah yang berujung pada terjadinya kesalahan penerjemahan dan kesalahpahaman. Penerjemahan sendiri merupakan proses yang hasil akhirnya menuju pada pengalhan bahasa sasaran yang mempunyai bobot arti yang sama atau mendekati bahasa sumber. Hal tersebut, sejalan dengan pendapat Catford (1969, hlm 20), yang menungkapkan"the replacement of textual material in one language by equivalent textual material in another language," sehingga prosesnya merupakan penggantian materi suatu teks dalam bahasa sumber dengan materi teks yang sepadan dalam bahasa sasaran. Selain itu Simatupang (2000, hlm. 20) pun berpendapat sama bahwa menerjemahkan adalah proses pengalihan makna dari bahasa sumber ke dalam bahasa sasaran.

Penerjemahan sendiri terbagi menjadi dua bagian. Pertama penerjemahan tulisan (honyaku) adalah memperbaiki naskah yang tertulis pada suatu bahasa ke dalam bahasa lain (Umesao dalam Muhlisian,2013, hlm 14). Sedangkan yang kedua penerjemahan lisan (tsuyaku) yaitu berdiri di antara dua orang yang masing-masing berbeda bahasanya, kemudian mengalihbahasakan masing-masing bahasa kedua orang tersebut (Tadao dalam Muhlisian, 2013, hlm 15). Dalam penelitian ini hanya menganalisis penerjemahan secara tertulis atau honyaku. Analisisnya berdasarkan bentuk penerjemahan langsung karya ilmiah serta berdasarkan penerjemahan bentuk atau struktur bahasa yang digunakan. Penerjemahan merupakan suatu hal yang kompleks yang tidak dapat terlepas dari dua faktor yang berpengaruh dalam proses penerjemahan, yakni faktor linguistik dan latar budaya. Kedua faktor ini dapat mengakibatkan kesalahan dalam penerjemahan, terutama dalam penerjemahan teks formal, misalnya karya ilmiah.

Secara umum istilah kesalahan ini mempunayai definisi tersendiri terutama dalam kesalahan berbahasa. Istilah kesalahan berbahasa menurut Corder (1974, hlm 1) dapat berarti lapses, error, atau mistake. Lapses adalah kesalahan berbahasa akibat dari penutur beralih cara untuk menyatakan 
sesuatu sebelum seluruh tuturan kalimat selesai dinyatakan selengkapnya. Error adalah kesalahan berbahasa akibat penutur melanggar kaidah atau aturan tata bahasa (branches of code). Sedangkan mistake adalah kesalahan berbahasa akibat penutur tidak tepat memilih kata atau ungkapan untuk situasi tertentu. Hal ini diperkuat oleh pendapat Sakoda (2002, hlm, 1125), yang mengungkapkan ada tiga macam klasifikasi kesalahan berbahasa dalam penelitian analisis kesalahan. Yang pertama adalah klasifikasi mistake dan error. Mistake merupakan kesalahan yang terjadi karena faktor kelelahan atau lupa sehingga penutur kurang tepat menggunakan kata atau ungkapan untuk situasi tertentu, sedangkan error adalah kesalahan yang secara konsisten muncul disetiap situasi dan lingkungan. Klasifikasi yang kedua adalah Global error dan Local Error. Global error mengacu kepada kesalahan yang mengakibatkan tidak tersampaikannya maksud kalimat penutur kepada lawan bicara local error adalah kesalahan yang tidak terlalu berpengaruh pada pemahaman lawan bicara terhadap maksud kalimat yang disampaikan oleh penutur. Klasifikasi ketiga adalah Intralingual error dan interlingual error. Intralingual error muncul akibat pengaruh bahasa ibu terhadap bahasa kedua tetapi interlingual error terjadi akibat kesalahan penggunaan suatu bahasa kedua dalam proses pembelajarannya.

Selanjutnya, Sakoda (2002, hlm, 29-32) juga mengatakan bahwa kesalahan berbahasa yang terus menerus dilakukan dapat terjadi karena kesalahan tersebut telah menjadi kebiasaan sehingga terjadi fossilization atau kebiasaan melakukan kesalahan yang sukar diperbaiki. Menurutnya, fosilisasi ini dapat disebabkan oleh lima hal, yakni:

1) 言語転移 (Language Transfer), yaitu ketika ada pengaruh bahasa ibu terhadap bahasa kedua yang dipelajari sehingga menimbulkan kesalahan berbahasa.

2) 過剩一般化 (Overgeneralization), yaitu ketika ada kesalahan yang disebabkan oleh ketidakmampuan pembelajar dalam menguasai aturan-aturan bahasa kedua (bahasa sasaran).

3）訓練上の転移（Transfer of Training）， yaitu ketika ada kesalahan yang terjadi akibat pengaruh negatif yang muncul ketika 
pengajar menyampaikan materi dengan menggunakan dua bahasa yang berbeda. Contohnya saat penutur/pengajar menggunakan kata「私は〜」 yang diucapkan berulang-ulang pada setiap kalimat.

4）学習ストラテジー (Learning Strategy), yaitu ketika ada kesalahan yang berhubungan dengan metode pembelajaran yang kurang tepat. Contohnya, untuk mengingat kata "arigatou" dalam bahasa Jepang, pembelajar (yang berbahasa ibu bahasa Inggris) menggunakan kata “Alligator”（アリゲーター：小型のワニ） yang bermakna "buaya," sehingga saat menyapa orang Jepang ia mungkin keliru menggunakan kata "Crocodile," (artinya juga sejenis "buaya"), karena yang diingat adalah maknanya ("buaya"), sehingga menjadi salah.

5） コミュニケーションストラテジー（Communication Strategy)

: Adanya kesalahan yang didasarkan pada kurangnya pengetahuan dan kemampuan berkomunikasi atau yang diakibatkan oleh keadaan saat penutur tidak bisa mengucapkan kata atau ungkapan tertentu dan kemudian dia ganti dengan kata lain.

Menyadari kemungkinan terjadinya kesalahan-kesalahan berbahasa tersebut di atas, peneliti tertarik untuk mendeskripsikan kesalahan penggunaan kata dalam teks hasil terjemahan Indonesia-Jepang dalam karya ilmiah mahasiswa.

Kata merupakan objek kajian sintaksis terkecil yang secara hirearkial menjadi komponen pembentuk sintaksis yang lebih besar yaitu frase. Hal senada diungkapkan oleh Kridalaksana(2008) bahwa kata merupakan satuan terkecil dalam sintaksis yang berasal dari laksem yang telah mengalami proses morfologi. Kata sangat diperlukan sebagai unsur pembentuk frase, klausa, kalimat dan juga wacana. Istilah kata dalam bahasa Jepang disebut kotoba. Bahasa Jepang merupakan salah satu bahasa di dunia yang memiliki keanekaragaman dalam hal tata bahasanya. Salah satu jenis keanekaragaman tersebut adalah pembagian kelas kata. Bahasa Jepang memiliki berbagai kelas kata. Sudjianto (2004:15) menyatakan bahwa kosakata dalam bahasa Jepang dapat diklasifikasikan ke dalam10 kelompok kelas kata yakni doushi(動詞)‘verba’, i-keiyoushi(イ形容詞)‘ajektiva- 
i'atau ada juga yang menyebutkan keiyoushi(形容詞), na-keiyoushi ( ナ形容詞)'ajektiva-na' atau ada juga yang menyebutkan keiyoudoushi( 形容動詞)，meishi(名詞)‘nomina’，fukushi(副詞)‘adverbia’, rentaishi( 連体詞)'pronomina',setsuzokushi(接続詞), 'konjungsi',kandoushi（感 動詞)'interjeksi',jodoushi(助動詞)‘verba bantu’, dan joshi(助詞)'kata’. Dalam penelitian ini akan dibahas adalah kesalahan penerjemahan kata.

Penelitian ini bertujuan mengungkapkan kesalahan penggunaan kata bahasa Jepang dalam teks hasil terjemahan Indonesia-Jepang. Selain itu, dilakukan juga pembahasan tentang penyebab munculnya kesalahan tersebut. Data penelitian ini diambil dari bagian latar belakang sembilan karya ilmiah mahasiswa Pendidikan Bahasa Jepang, Sekolah Pascasarjana Universitas Pendidikan Indonesia di Bandung. Penulis berpendapat bahwa bagian latar belakang dari suatu laporan penelitian merupakan hasil pemikiran orisinal penulis karya ilmiah tersebut, jadi dapat merepresentasikan kemampuan kebahasaan peneliti.

\section{Metode Penelitian}

Salah satu jenis penelitian kualitatif deskriptif adalah penelitian studi kasus (Case Study). Fenomena yang menjadi kasus dalam penelitian ini adalah kesalahan penerjemahan yang kerap muncul dalam penerjemahan karya ilmiah bahasa Indonesia ke dalam bahasa Jepang. Sumber data penelitian ini adalah sembilan latar belakang karya ilmiah mahasiswa S2 Prodi Pendidikan Bahasa Jepang SPs Universitas Pendidikan Indonesia. Latar belakang karya ilmiah diambil sebagai objek penelitian dengan pertimbangan bahwa latar belakang penelitian merupakan pemikiran murni dari penulis karya ilmiah dalam membuat karya tulis penelitian.

Selanjutnya, data dalam bahasa Jepang yang telah terkumpul diserahkan kepada dua orang penutur asli bahasa Jepang yang mengerti bahasa Indonesia yang bertugas memberikan expert judgement atau penilaian pakar terhadap hasil terjemahan para mahasiswa tersebut. Penilaian pakar ini digunakan untuk mendeskripsikan kesalahan penerjemahan apa saja yang ditemukan dan untuk menjelaskan penyebab terjadinya kesalahan penerjemahan tersebut. 


\section{Hasil dan Pembahasan}

Berdasarkan hasil analisis data, ditemukan banyak kesalahan berdasarkan kata. Kesalahan kata ini banyak ditemukan baik dikarenakan oleh penghilangan, penambahan, kesalahan penulisan huruf, ketidaksesuaian penggunaan kosakata dalam kalimat ataupun kesalahan dalam perubahan kata yang seluruhnya berjumlah 80 kesalahan.

Tabel Kesalahan Penggunaan Kata

\begin{tabular}{|c|c|c|}
\hline \multicolumn{1}{|c|}{ Item } & Frekuensi & Persentase \\
\hline 1. Kesalahan addition dan omission & 12 & 15.00 \\
a. Kesalahan addition & 10 & 12.50 \\
b. Kesalahan Omission & 11 & 13.75 \\
2. Kesalahan penulisan huruf katakana & 11 & 13.75 \\
3. Kesalahan penulisan kanji & 26 & 32.50 \\
4. Kesalahan pengunaan kosakata yang & & \\
tidak sesuai dalam kalimat & 10 & 12.50 \\
5. Kesalahan perubahan kata & 80 & $100 \%$ \\
\hline
\end{tabular}

Lebih rinci penjelasan mengenai kesalahan penggunaan kata terdapat pada data di bawah ini.

1) Kesalahan penambahan (addition) atau penghilangan kata (omission).

a. Kesalahan penambahan kata baik dalam bentuk kata sambung, penambahan huruf dan kata lainnya terdapat 12 kesalahan. Contohnya seperti kalimat di bawah ini,

Data teks mahasiswa

Efektifitas model pembelajaran bahasa Jepang di SMA Negeri Cisarua 
dengan menggunakan teknik Information Gap melalui pendekatan komunikatif.(T1-1)

Data terjemahan mahasiswa (誤用)

Cisarua 高等学校におけるインフォメーションギャップ方法を使 用する学習

モデルの効果的分析(T1-1)

Saran terjemahan(正用)

Cisarua 高等学校におけるインフォメーションギャップ法を使用 する学習モ

デルの効果的分析

Pada kalimat (T1-1) di atas terjadi kesalahan dalam bentuk penambahan kata atau addition pada kata Teknik Information Gap diterjemahkan ke dalam bahasa Jepangインフォメーションギャップ方 法. Penerjemahan teknik dengan kata方法 adalah kesalahan karena pada kalimat di atas Teknik Information Gap merupakan satu frase sehingga untuk menerjemahkan teknik cukup menggunakan satu kanji saja yakni 法 yang sudah mencakup makna cara atau teknik yang dimaksud di atas. Sehingga frase yang benar adalah インフォメーションギャップ法. Kesalahan di atas termasuk local error karena tidak terlalu berpengaruh pada makna yang ingin disampaikan. Penyebab kesalahan ini adalah ketidakmampuan penerjemah dalam menguasai aturan-aturan bahasa kedua sehingga terjadi overgeneralisasi bahasa. Kalimat lainnya yang mempunyai kesalahan penerjemahan terdapat pada kalimat di bawah ini:

Data teks mahasiswa

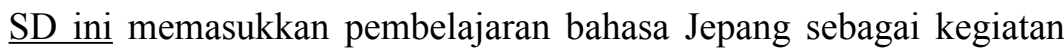
ekstra kurikuler (ekskul) (T2-1a)

Data terjemahan mahasiswa(誤用)

それは、この小学校では日本語教育を課外活動として実行し ている

Saran terjemahan(正用) (T2-1a)

この小学校では日本語教育を課外活動として実行している Penggunaan それは_pada kalimat (T2-1a) tidak perlu karena tidak ada 
padanannya pada kalimat bahasa Indonesia. Kesalahan ini termasuk kesalahan lokal dan disebabkan oleh kebiasaan bahasa Indonesia 'yaitu’ dalam kalimat sehingga terjadi language transfer.

b. Kesalahan penghilangan (omission) kata terdapat 10 kesalahan. Contohnya seperti kalimat di bawah ini,

Data teks mahasiswa

Penyebab hal itu adalah akibat masih adanya kekacauan view point pada JFL yang tidak menyadari adanya prinsip shiten no ikkansei dalam sebuah kalimat. (T3-4a)

Data terjemahan mahasiswa (誤用)

その不自然さは、談話における「視点の一貫性」の意識していない 上深く関

連していることが指摘されている(T3-4a)

Saran terjemahan(正用)

その不自然さは、談話における「視点の一貫性」の意識していない ことと深

く関連していることが指摘されている。

Pada kalimat (T3-4a) di atas terjadi kesalahan penerjemahan berupa penghilangan kata sehingga berpengaruh pada makna yang ingin disampaikan. Yang ditekankan pada kalimat di atas adalah hal "yang menyebabkan kekacauan View point adalah JFL yang tidak menyadari adanya prinsip....”. . Hal ini yang harus diterjemahkan ke dalam bahasa Jepang agar jelas maksud dari kalimat tersebut. Sehingga terjemahan yang benar adalah”....意識していないこと と深く関連していることが指摘されている”. Kesalahan di atas termasuk kesalahan lokal karena tidak terlalu berpengaruh terhadap makna yang akan disampaikan. Penyebab dari kesalahan tersebut adalah kelalaian penerjemah yang disebabkan oleh tidak sampainya pengetahuan penerjemah terhadap bahan yang diterjemahkan atau tidak munculnya pola atau kosakata yang ingin disampaikan sehingga cenderung menghilangka kosakata atau pola yang sulit tersebut, sehingga menimbulkan kesalahan communication strategy. Kalimat lainnya yang mengalami kesalahan omission . 
Data teks mahasiswa

Bukan dari tingkat ilmuan saja, tetapi tingkat dasar pun terlihat masih lemah dalam

$\underline{\text { menulis, }}$ khususnya yang terlihat didalam dunia pendidikan tingkat SMA .(T6-2b)

Data terjemahan mahasiswa (誤用)

中等教育、特に高校レベルの書く能力がまだ低いのもよく見ら れる。(T6-2b)

Saran terjemahan(正用)

中等教育、特に高校レベルの母語の書く能力が低い現状もよく 見られる。

2) Kesalahan penggunaan huruf katakana yang menimbulkan kerancuan makna. Kesalahan yang ditemukan terdapat 11 kesalahan. Contohnya seperti di bawah ini,

Data teks mahasiswa

Aizuchi digunakan sebagai tanda bahwa pembicara setuju dengan kalimat yang diucapkan sebelumnya, sebagai ungkapan emosi pembicara, juga sebagai 'pancingan' agar percakapan berjalan dengan alur yang lebih menarik (T4-3c)

Data terjemahan mahasiswa (誤用)

そのあいづちは「聞いている」という機能ではなく、「Continuer $」$ やフィ

ニラー」や「同意」などの機能に近いと考えられる。(T4-3c)

Saran terjemahan(正用)

そのあいづちは「聞いている」という機能ではなく、「Continuer $」 や 「 フ ィ$

ラー」や「同意」などの機能に近いと考えられる。

Huruf katakana adalah huruf yang biasa digunakan oleh orang Jepang untuk menuliskan kata serapan asing seperti nama orang asing, Negara, atau istilah-istilah dari bahasa asing. Namun, yang harus difahami oleh pembelajar bahasa Jepang orang asing adalah, dalam penulisan kata 
serapan asing tersebut orang Jepang menggunakan logat atau pelafalan bahasa Jepang, sehingga saat ditulis ke dalam huruf katakana maka cara baca atau pelafalannya akan berbeda dengan pelafalan bahasa asing sebenarnya. Hal itu yang menyebabkan banyaknya terjadi kesalahan penulisan katakana seperti pada kalimat (T4-3c) di atas, kata 'pancingan' atau dalam bahasa Inggris disebut filler, saat ditulis dengan huruf katakanaフィーラーmenjadi sebuah kesalahan. Karena yang seharusnya pada penulisan bahasa Jepang yang ditulis panjang adalah akhirannya saja. Sehingga kata tersebut ditulis 7 イラー. Kesalahan ini merupakan kesalahan lokal (local error) karena tidak terlalu berpengaruh pada perubahan makna yang akan disampaikan. Penyebab kesalahan ini dapat berupa language transfer dimana pelafalan bahasa pertama mempengaruhi bahasa kedua dapat pula disebabkan oleh transfer of training dimana terdapat pengaruh negative yang muncul ketika pengajar menyampaikan materi dengan dua bahasa yang berbeda yang mengakibatkan penulisan katakana menjadi salah. Kalimat lain yang mempunyai kesalahan penulisan katakana terdapat pada kalimat seperti di bawah ini.

Data teks mahasiswa

Salah satu permasalahan yang cukup penting adalah "bagaimana mengembangkan kemampuan berbahasa kepada siswa sehingga dapat mereka dapat menggunakan bahasa dalam berbagai fungsinya" (T6-1a) Data terjemahan mahasiswa (誤用)

その問題の一つは「いろいろな場面で使えるような言語をどうし たら学生に

教えるのか」カリキューラムの目標にには学生は学校で習った正 確な日本語

$$
\text { で「思想を現わすことができる(T6-1a) }
$$

Saran terjemahan(正用)

その問題の一つは「いろいろな場面で使えるような言語表現をど のように学

生に教えたらよいのか」カリキュラムの目標にには学生は学校で 習った正

確な日本語で「考えを表すことができる 
3) Kesalahan penulisan kanji sehingga menimbulkan kerancuan makna. Kesalahan yang ditemukan terdapat 11 kesalahan. Contoh kesalahan seperti di bawah ini,

Data teks mahasiswa

Dengan alasan tersebut, dapat diasumsikan bahwa gaya belajar merupakan salah satu faktor penting dalam proses pembelajaran bahasa asing. (T2-3c)

Data terjemahan mahasiswa(誤用)

その理由で、学習スタイルが外国語教育の教授・学習活動の一 つの大切な要

$$
\text { 素であるということが億節できる(T2-3c) }
$$

Saran terjemahan(正用)

その理由で、学習スタイルが外国語教育の教授・学習活動の一 つの大切な要

\section{素であるということが憶測できる}

Penggunaan kanji dalam kalimat sangat berpengaruh pada maksud dari kalimat yang ingin disampaikan, sehingga penulis haruslah berhatihati dalam memilih kanji apa yang ingin dipakai dalam menulis sebuah kalimat, bila penulisan kanjinya salah maka maknanya pun akan berubah jauh dari maksud yang akan disampaikan. Seperti pada kalimat (T2-3c), penggunaan kanji yang salah menimbulkan makna yang berbeda. maksud yang ingin disampaikan dalam kalimat di atas adalah menerjemahkan kata diasumsikan dengan menggunakan kanji億節(オクセツ).Namun kanji tersebut mengandung arti yang jauh berbeda dengan kata yang dimaksudkan. Kanji yang tepat untuk kata asumsi adalah憶測(オクソ ク). Kesalahan ini dapat dikategorikan sebagai kesalahan global (global error) karena kesalahan penulisan kanji dapat menimbulkan kesalahan penafsiran makna kalimat yang ingin disampaikan. Penyebabnya dapat berupa kesalahan dalam pengetikan atau lapses ataupun overgeneralisasi yang dikarenakan kurangnya penguasaan terhadap kaidah bahasa. Kalimat lain yang mempunyai persamaan kesalahan kanji terdapat pada kalimat di bawah ini. 
Data teks mahasiswa.

Selain itu, hasil perbandingan antara kedua bahasa dapat digunakan untuk meramalkan kesulitan; dengan mengetahui bagaimana mengatasi kendala yang bersumber dari faktor internal bahasa, diharapkan dapat dimanfaatkan dalam proses pembelajaran (T4-5b)

Data terjemahan mahasiswa(誤用)

結果として、インドネシアで日本語教育の世界に貢献できると よい両言語の

特徵や相違点を明らかにすることにより、なめらかな日本語会 話を学習する

$$
\text { のに役に立てるのではないかと考えている(T4-5b) }
$$

Saran terjemahan(正用)

本調査の結果が、インドネシアで日本語教育の分野に貢献でき るとよい。両

言語の特徵や相違点を明らかにすることにより、なめらかな日 本語会話を学

\section{習するために役立てるのではないかと考えている}

4) Kesalahan penggunaan kata yang tidak sesuai dengan kalimat. Kesalahan yang ditemukan terdapat 26 kesalahan. Contoh kalimat yang menunjukkan kesalahan tersebut seperti di bawah ini, Data teks mahasiswa

Seperti yang diungkapkan oleh Tarigan dan Tarigan dalam bukunya Teknik Pengajaran Keterampilan Berbicara (1990: 88), keadaan pengajaran berbicara sejalan dengan pengajaran Bahasa Indonesia, belum memuaskan, keterampilan berbicara dalam arti luas, para pengajar belum memadai. Untuk menyiasati pengajaran keterampilan berbicara dengan baik, guru harus menyajikan pengajaran dengan menarik agar merangsang siswa untuk aktif berbicara. (T1-4)

Data terjemahan mahasiswa (誤用)

タリガンは高校生はインドネシア語の言語能力でさえ十分では ない。したが 
つて教師は「話す力」に対する意欲を向上させるため、教育方 法を考え、魅

力ある教育を提供する必要があるといっている（1990：88） (T1-4)

Saran terjemahan(正用)

タリガンは高校生はインドネシア語の言語能力でさえ十分では ない。したが

って教師は「話す力」に対する意欲を向上させるため、教育方 法を考え、魅

力ある教育を提供する必要があると述べている（1990：88）

Pada kalimat (T1-4) di atas, penggunaan akhiran といっている sebagai terjemahan dari kata diungkapkan merupakan penerjemahan yang kurang tepat karena merupakan penulisan bahasa lisan. Yang benar penerjemahan di atas di gunakan kata と述べている. Sehingga penerjemahan yang benar adalah ”.....魅力ある教育を提供する必要があると述べてい る (1990 : 88) ". Kesalahan ini termasuk kesalahan lokal karena tidak terlalu berpengaruh terhadap makna yang akan disampaikan. Penyebab kesalahan ini termasuk ke dalam kesalahan communication strategy yang diakibatkan oleh kurangnya penguasaan terhadap kosakata atau struktur bahasa jepang yang tepat dalam kalimat yang menyebabkan terjadinya kesalahan. Penyebab lainnya dapat berupa kesalahan yang muncul akibat pengaruh bahasa ibu terhadap bahasa kedua atau disebut language transfer seperti terlihat pada contoh (T4-4b) atau kesalahan yang disebabkan oleh Learning Strategy berhubungan dengan metode pembelajaran yang salah menimbulkan kesalahan dalam berbahasa (T8-2b). Kalimat lainnya adalah:

Data teks mahasiswa

Dalam pembelajaran maupun pemerolehan bahasa asing, ketidaksesuaian antara gaya belajar pembelajar dan gaya (cara) mengajar pengajar dapat saja terjadi dengan serius. (T2-3b)

Data terjemahan mahasiswa (誤用)

学習でも習得でも、教師の教授スタイルと学習者の学習スタイ 
ルとの重大な

不適当さが起こる可能性がある(T2-3b)

Saran terjemahan(正用)

学習でも習得でも、教師の教授スタイルと学習者の学習スタイ ルとの重大な

ずれが生じる可能性がある

5) Kesalahan perubahan kata dalam kalimat. Kesalahan yang ditemukan terdapat 10 kesalahan. Contoh kalimat yang menunjukkan kesalahan perubahan kata dalam kalimat terdapat pada kalimat di bawah ini,

Data teks mahasiswa

Tokoh dengan kecenderungan empati yang tinggi merupakan tokoh yang menjadi posisi view point pencerita. (T3-5)

Data terjemahan mahasiswa (誤用)

話し手の高く共感度を得る談話人物が話し手の視点になる。(T35)

Saran terjemahan(正用)

話し手の高い共感度を得る談話人物が話し手の視点になる。

Pada kalimat (T3-5), terdapat kesalahan bentuk perubahan kata sifat yang tidak sesuai dengan fungsi kata sifat yang dipakai dalam kalimat tersebut sehingga menimbulkan kerancuan makna. Pada kalimat di atas, untuk menunjukkan kata tinggi untuk menjelaskan 'empati yang tinggi' sebenarnya kata sifat tinggi tidak mengalami perubahan menjadi bentuk 高く, karena bentuk <pada kata sifat berfungsi untuk menyambungkan dengan kalimat lain atau dengan kata sambung lain seperti 〜高くなります、 高くないです sedangkan saat menerangkan kata benda dipakai kata sifat bentuk い. Kesalahan tersebut termasuk ke dalam kesalahan lokal karena tidak menghambat komunikasi pesan yang akan disampaikan. Penyebab kesalahan ini adalah ketidakmampuan penerjemah dalam menguasai aturan-aturan bahasa kedua sehingga terjadi overgeneralisasi bahasa. Kalimat lain yang mempunyai kesalahan perubahan bentuk kata dalam kalimat adalah: 
Data teks mahasiswa (T4-4a)

Jika respon (aizuchi) disampaikan pada waktu yang tidak tepat, ada kemungkinan si pendengar akan dicap sebagai orang yang tidak tahu sopan santun karena menginterupsi pembicaraan orang lain; juga menimbulkan kesan si pendengar tidak mau mendengar ucapan si pembicara (T4-4a)

Data terjemahan mahasiswa (誤用)

反応が不適切に使用すれば、聞き手は「無礼の人」だと思えら れ、「話を聞

$$
\text { きたくない」という印象を示している(T4-4a) }
$$

Saran terjemahan(正用)

反応が不適切に使用寸れば、聞き手は「無礼な人」だと思わ

れ、「話を聞き

$$
\text { たくない」という印象を与えてしまう }
$$

\section{Simpulan}

Rumusan masalah mengenai Kesalahan kata hasil terjemahan karya ilmiah mahasiswa berupa apa saja kesalahan kata yang muncul dan apa penyebab kesalahan tersebut muncul telah terjawab yakni sebagai berikut:

1) Kesalahan kata yang muncul terdapat 5 bentuk kesalahan dengan frekuensi kemunculan sebanyak 80 kesalahan. Kesalahan yang paling dominan muncul adalah kesalahan penggunaan kata yang tidak sesuai dalam kalimat. Penyebab kesalahan ini termasuk ke dalam kesalahan communication strategy yakni kurangnya penguasaan terhadap kosakata atau struktur bahasa jepang yang tepat dalam kalimat yang menyebabkan terjadinya kesalahan. Penyebab lainnya dapat berupa kesalahan yang muncul akibat pengaruh bahasa ibu terhadap bahasa kedua atau disebut language transfer yang mengakibatkan tidak tersampaikannya maksud yang ingin dicapai penulis. Selain itu, saat menerjemahkan karya ilmiah dari bahasa Indonesia ke dalam bahasa Jepang, sebaiknya melihat dulu pedoman penerjemahan bahasa Jepang yang baik sehingga kesalahan tidak muncul. Melakukan pengecekan berulang terhadap hasil terjemahan untuk memperkecil kesalahan dalam menerjemahkan. 
2) Penyebab kesalahan adalah; kesalahan sebagian besar berupa mistakes dalam bentuk kesalahan lokal (local error). Kesalahan tersebut berupa mistakes dalam bentuk kesalahan lokal dikarenakan kesalahan yang muncul secara umum tidak mempengaruhi maksud yang ingin disampaikan penulis. Penyebab terjadinya kesalahan penerjemahan bahasa Jepang dalam karya ilmiah mahasiswa tersebut pada dasarnya disebabkan oleh 5 faktor, yaitu, 1) Language Transfer, 2) Overgeneralization, 3) Transfer of Training,, 4) Learning Strategy , 5) Communication Strategy. Dari kelima faktor penyebab kesalahan tersebut semuanya harus diperhatikan agar kesalahan yang sama tidak terjadi pada penerjemahan berikutnya adalah kesalahan communication strategy yakni kurangnya penguasaan terhadap kosakata atau struktur bahasa jepang yang tepat dalam kalimat yang menyebabkan terjadinya kesalahan.

Penelitian ini lebih banyak berkutat dimasalah kesalahan dilihat dari kata saja, penelitian ini belum menyentuh tataran lain dalam struktur kalimat bahasa Jepang. Untuk penelitian selanjutnya penulis menyarankan agar analisis kesalahan penerjemahan ini dapat diteliti dari sudut pandang lainnya selain kata, seperti frase, ataupun pola kalimat, dengan menggunakan objek penelitian lain agar kesalahan penerjemahan yang terjadi dapat diperkecil sehingga maksud yang akan disampaikan dapat diterima dengan baik oleh pembaca dan pemakai bahasa sasaran. Semoga penelitian ini dapat berguna bagi dunia pendidikan, terutama pendidikan bidang penerjemahan teks Indonesia-Jepang, agar hasilnya lebih baik.

\section{Daftar Pustaka}

Catford, J.C. (1969). A Linguistic Theory of Translation, London: Oxford University Press.

Corder. P. (1974). The Significance of Learner's Error. International Review Of Applied Linguistics 5. Pp. 161-170.

Kridalaksana, Harimurti. 1993. Kamus Linguistik Edisis III. Jakarta : PT Gramedia. 
Muhlisian, Asep Achmad. (2013). Analisis Kesalahan Terjemahan Bahasa Jepang yang Terdapat Dalam Karya Ilmiah Mahasiswa S2. Thesis:UPI Bandung.

Simatupang, Maurits D.S. (2000). Pengantar Teori Terjemahan. Jakarta: Direktorat Jendral Pendidikan Tinggi Depdiknas.

Sudjianto. (2000). Gramatika Bahasa Jepang Modern. Bandung: Ksaint Blanc.

Sakoda, Kumiko.2002. Nihongo kyouiku ni Ikasu : Dai Ni Gengo Shutoku, Tokyo: Aruku 